\title{
F-Actin-Capping Protein Subunit Alpha-2
}

National Cancer Institute

\section{Source}

National Cancer Institute. F-Actin-Capping Protein Subunit Alpha-2. NCI Thesaurus. Code C132074.

F-actin-capping protein subunit alpha-2 (286 aa, $\sim 33 \mathrm{kDa})$ is encoded by the human CAPZA2 gene. This protein is involved in the inhibition of actin polymerization and depolymerization. 